ACRL Statement on Access and the 1974 Standards for Access of SAA (American Archivist, Janu-

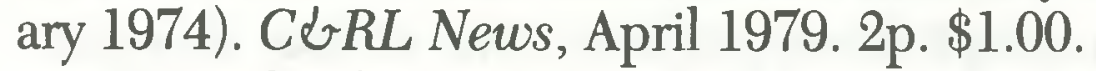

- Standards for Ethical Conduct for Rare
Book, Manuscript, and Special Collections Libraries. RBMS Committee on Developing Guidelines for Professional Ethics. C $\mho R L$ News, March 1987. 2p. $\$ 1.00$.

\title{
ACRL publishing procedures
}

\section{How to publish in ACRL.}

ublications are a vital part of academic librarianship and the ACRL program. One of the purposes of ACRL is to promote and disseminate its members' and units' work in the fields of their expertise. The ACRL publications program is one major means of engaging in this promotion and dissemination. Publishing was identified as the number one priority of ACRL members in a recent survey and ACRL units and members are generating ideas and projects that have publication potential in either a print or non-print format.

It is important that work completed by ACRL units be offered to ACRL for first publication consideration. Work of ACRL units may take the form of news articles, journal articles, bibliographies, directories, monographs, databases, survey results, pamphlets, cassettes, software and the like.

This document outlines procedures to assist ACRL units and individuals in their publishing endeavors. It sets down an orderly process for submitting manuscripts to ACRL publications and encourages communication between authors or editors and ACRL, to ensure that ACRL publications maintain a high quality.

For the purposes of this document, unit is defined as any official group within ACRL (section, committee, subcommittee, discussion group or the like); author is defined as an individual or collection of individuals working independently without official designation from ACRL.

\section{ACRL publishing}

ACRL has the first publication option on all work prepared for publication by an ACRL unit. For example, work produced by an ACRL unit that is of article length must be submitted to the appro- priate ACRL periodical for consideration before sending the article to an outside journal. Procedures for submitting items for publication for units and individuals are described in a separate section of this document. Submitted manuscripts should follow the Chicago Manual of Style, 13th edition.

The types of work prepared may be appropriate for publication in an ACRL periodical, by ACRL publishing, by ALA Publishing Services, or by an outside publisher. The types of material published by these organizations are described below. ACRL also welcomes publication ideas and manuscripts from individuals.

\section{Opportunities for publishing}

1.ACRL periodical publications. ACRL periodicals include: College and Research Libraries, College and Research Libraries News, Rare Books and Manuscripts Librarianship, Choice, and section newsletters. ACRL members serve on editorial boards for each of these periodicals. Guidelines for submission to these periodicals are found in the respective periodicals.

2. ACRL Publications in Librarianship. This series publishes monographs pertinent to all aspects of academic and research librarianship. ACRL members are appointed to serve on the editorial board for this series and the series is published by ALA Publishing Services. Ideas and manuscripts should be sent to the chair of the ACRL Publications in Librarianship Editorial Board.

3. CLIP Notes. CLIP Notes (College Library Information Packets) collect data and sample documents from academic libraries to assist librarians in establishing or refining services and opera- 
tions. The surveys are authorized by ACRL's College Libraries Section CLIP Notes Committee. Recent topics in this series have included annual reports, friends groups, periodicals, student workers, and mission statements. Ideas for future CLIP Notes should be sent to the chair of the CLS CLIP Notes Committee.

4. Non-periodical publications. Works (other than monographs) pertinent to academic and research librarianship may be published by ACRL. ACRL has published a variety of materials including, but not limited to, statistical reports, directories, survey results, handbooks, bibliographies, and thesauri. Typically, ACRL publications have an intended audience of 500 to 1,500, are self-supporting, and are printed from camera-ready copy supplied by the author (directions for preparing this camera-ready copy are provided by the ACRL office). Proposals should be sent to the ACRL publications officer at ACRL headquarters.

5. Choice Bibliographic Essays. This series, published by Choice magazine, is for bibliographies on selected topics of interest to academic and research librarians. Recent titles in the series have focused on women's studies, children's literature, and vocational and technical collection development. Proposals should be sent to the editor of Choice.

6. ALA Publishing Services. ACRL may, at its discretion, offer the work developed by an ACRL unit to ALA Publishing Services. This ensures ALA the opportunity to disseminate works prepared under its auspices. ALA Publishing generally accepts items for publication that make a contribution to librarianship and that can sustain sales of at least 1,500 to 2,000 copies.

7. Outside publishers. If a manuscript is not deemed appropriate for any of the publishing outlets listed above (or if the terms offered by ALA Publishing are not acceptable) the ACRL staff will assist units with the submission of manuscripts to outside publishers.

Procedures to be followed in such a submission are included in this document.

\section{Submission procedures to ACRL}

\section{Article-length works}

Step one. Identify a topic and review the submission guidelines found in the pertinent ACRL periodical (College and Research Libraries, College and Research Libraries News, Rare Books and Manuscripts Librarianship, Choice, and section newsletters).

Step two (for units and individuals). Depending on the guidelines either contact the editor to review the idea for publication potential or prepare and submit a finished manuscript.

Step two (for sections). Same as step two above but forward the completed manuscript to the unit's chair. The unit executive committee will review the manuscript for appropriateness or may delegate such review to another appropriate group, such as the unit's publication's committee. If the manuscript is approved, the unit chair will forward it to the appropriate ACRL periodical.

Step three. The ACRL periodicals will follow the selection procedures outlined in the publication.

Step four. The editor will notify the author or unit and the ACRL publications officer as to whether or not the article has been accepted for publication. If the article is not accepted the unit may submit the article to any other appropriate periodical for publication.

Step five. Information about the articles submitted by an ACRL unit will be entered on a database of publications in process maintained by the ACRL publications officer at ACRL headquarters. This database will help ACRL keep track of all of the efforts of its units. ACRL staff will monitor the database and alert groups who may be working on similar projects.

\section{Publications other than journal articles}

Separate procedures are listed for the various publishing opportunities within ACRL.

\section{ACRL Publications in Librarianship}

Step one. Identify a topic and develop an outline for your publication.

Step two. Send your idea to the editor of Publications in Librarianship.

Step three. The editorial board will review the proposal and either advise on its development, refer it to another place to publish or return the proposal with regrets.

Step four. The editor will notify the ACRL publications officer of all publication proposals received from ACRL units so that they may be entered on the database of work in progress.

\section{ACRL/CLS CLIP Notes}

Step one. Identify a topic and contact CLIP Notes committee chair for information on proposal format or contact chair to discuss topics that have been previously identified.

Step two. Develop an outline of your proposal and submit to the chair of the CLS Clip Notes Committee.

Step three. The CLIP Notes Committee will review the proposal and either advise on its development, refer it to another place to publish or return the proposal with regrets.

Step four. The chair of the committee will notify the ACRL publications officer of all publication proposals received from ACRL units so that they 
may be entered on the work-in-progress database.

\section{ACRL Non-serial publications}

Step one (for individuals). Identify a topic and develop an outline for your publication. Fill out a "Preliminary Publication Information Form," available from ACRL Headquarters, early in the planning stages of your project. This form asks for basic information about the scope and content of the proposed publication and the individual(s) responsible for developing it. Send the completed form to ACRL's publications officer at ACRL Headquarters.

Your proposal will be entered in a database of publications in progress at ACRL Headquarters. This database will help ACRL keep track of all of the efforts of its units and members. ACRL staff will monitor the database and alert groups who may be working on similar projects.

Step one (for units). Same as step one above but forward the completed form to the unit's executive committee. The unit executive committee will review the publication proposal or delegate such review to another appropriate group such as its publications committee and if they approve it will forward it to the ACRL publications officer at ACRL Headquarters.

Step two. The ACRL publications officer reviews the proposal and notifies ALA Publishing Services of the proposal. ACRL cooperates with ALA Publishing Services and allows them the opportunity to consider the proposal as an ALA publication. If ALA Publishing Services is interested in the proposal, a publishing agreement is negotiated. If ALA Publishing is not interested in the proposal, the ACRL non-serial publication process continues with step three.

Step three. The ACRL publications officer will forward the proposal to the ACRL Non-Serial Publications Editorial Board for a review of its content and viability. The Editorial Board will make a recommendation to the publications officer as to its feasibility. (In some cases an outside reader with expertise in the subject area will be asked to review the publication for editorial content. This review will next be considered by the Editorial Board and the publications officer.) The Editorial Board will review and act upon publications proposals throughout the year, as well as at ALA annual conferences and midwinter meetings.

Step four. After reviewing the recommendations of the Editorial Board (and any outside reviewers) the ACRL publications officer then accepts, asks for further development of the proposal from the author or sponsoring body, or returns the proposal with regrets.

Step five. If the proposal is accepted, the author is requested to submit the completed manuscript (usually camera-ready) to ACRL Headquarters for final review.

\section{Choice Bibliographic Essays}

Step one. Identify a topic and develop an outline for your publication.

Step two. Send your idea to the editor of Choice.

Step three. The editor will review the proposal and either advise on its development, refer it to another place to publish, or return the proposal with regrets.

Step four. The editor will notify the ACRL publications officer of all publication proposals received from ACRL units so that they may be entered on the database of work in progress.

\section{Conference proceedings}

Step one. A unit which wishes to publish its conference proceedings or papers will submit its manuscript to ACRL.

Step two. Follow the same procedures outlined under ACRL Non-serial publications.

\section{Submission to outside publishers (by ACRL units)}

Step one. If a manuscript is not deemed appropriate for any of the ACRL or ALA publishing outlets described in this document (or if the terms offered by ALA Publishing Services are not acceptable) the ACRL staff will assist units with the submission of manuscripts to outside publishers.

Step two. The unit will notify the ACRL publications officer of their publications plan so that the database of works in process can be updated.

Step three. The executive director of ACRL must have the opportunity to review any contracts between an ACRL unit and a publisher.

Points of discussion between the unit and the prospective publisher may include: proposed publication date; format, including any particular needs regarding illustrations or typography; arrangement of bibliographical references, i.e., footnotes or endnotes; paper stock; binding; maximum sale price; minimum period during which the volume will remain in print; advertising (number of ads which will coincide with the date of publication); number of review copies to be provided by the publisher; date by which the unit will deliver the final manuscript to the publisher; size of print run; number of offprints for authors and a copy of the book for the editor. The contract must be signed by an ALA department head.

Any volume issued by a commercial publisher must clearly state on its title page and in the preface or introduction that the work was undertaken by an ACRL unit. 